\title{
Effect of feed intake on amino acid transfers across the ovine hindquarters
}

\author{
S. O. Hoskin ${ }^{1}$, I. C. Savary-Auzeloux ${ }^{2}$, A. G. Calder ${ }^{1}$, G. Zuur ${ }^{3}$ and G. E. Lobley ${ }^{1}$ \\ ${ }^{1}$ Rowett Research Institute, Bucksburn, Aberdeen AB21 9SB, Scotland, UK \\ ${ }^{2}$ INRA - Centre de Clermont-Ferrand/Theix, 63122 Saint Genes-Champanelle, France \\ ${ }^{3}$ Biomathematics and Statistics Scotland, Rowett Research Institute, Bucksburn, Aberdeen AB21 9SB, Scotland, UK
}

(Received 8 March 2002 - Revised 21 August 2002 - Accepted 6 September 2002)

\begin{abstract}
Responses in variables of amino acid (AA) metabolism across peripheral tissues to feed intake were studied in six sheep (mean live weight $32 \mathrm{~kg}$ ) prepared with arterio-venous catheters across the hindquarters. Four intakes $(0.5,1.0,1.5$ and $2.5 \times$ maintenance energy) were offered over 2-week periods to each sheep in a Latin square design with two animals replicated. Animals were infused intravenously with a mixture of $\mathrm{U}^{13}{ }^{13} \mathrm{C}$-labelled AA for $10 \mathrm{~h}$ and integrated blood samples withdrawn from the aorta and vena cava hourly between 5 and $9 \mathrm{~h}$ of infusion. Biopsy samples were also taken from skin and $m$. vastus lateralis. Data from both essential (histidine, isoleucine, leucine, lysine, phenylalanine, threonine) and nonessential (glycine, proline, serine, tyrosine) AA were modelled to give rates of inward and outward transport, protein synthesis and degradation, plus the fraction of total vascular inflow that exchanged with the hindquarter tissues. Rates of inward transport varied more than 10-fold between AA. For all essential AA (plus serine), inward transport increased with food intake $(P<0 \cdot 04)$. There were corresponding increases in AA efflux $(P<0.05)$ from the tissues for threonine and the branched-chain AA. Protein synthesis rates estimated from the kinetics of these AA also increased with intake $(P<0.02)$. Rates of inward transport greatly exceeded the amount of AA necessary to support protein retention, but were more similar to rates of protein synthesis. Nutritional or other strategies to enhance AA transport into peripheral tissues are unlikely to increase anabolic responses.
\end{abstract}

Amino acid transport: Protein metabolism: Feed intake: Hindlimb: Muscle: Skin: Sheep

Flexibility in partition of nutrients between tissues permits both short- and long-term adaptation to environmental and physiological stimuli. Intake can also regulate metabolic responsiveness, with the priority of nutrient use altered between 'visceral' and 'productive' tissues during underand overnutrition (Lobley, 1993). This alters the efficiency by which farmed species divert feed eaten to tissues such as muscle, skin and the mammary gland. While in such tissues certain aspects of protein metabolism, including synthesis and degradation, have been shown to alter with feed intake (e.g. Seve et al. 1986; Oddy et al. 1987; Dawson et al. 1991; Boisclair et al. 1993; Ponter et al. 1994; Liu et al. 1998; Hoskin et al. 2001) the involvement of other processes is less clear. For example, increases in feed intake are usually accompanied by elevated blood flow to peripheral tissues (e.g. Harris et al. 1994; Hoskin et al. 2001) and, in some cases, arterial concentrations of certain amino acids (AA) (Hoskin et al. 2001). These two factors, acting either in isolation or together, provide a greater vascular supply of most AA, but how this relates to transport into cells and subsequent use for protein metabolism is unclear. In other tissues, such as the mammary gland, transport of specific nutrients (glucose) is thought to limit metabolic activity (milk production; Cant et al. 1999) and here, nutritional, endocrinological or genetic approaches to enhance rates of transport appear attractive.

Whether similar strategies should be extended to increase AA transport in other peripheral tissues depends on whether transport of $\mathrm{AA}$ is a limitation to increasing protein synthesis and ultimately net protein accretion. Unfortunately, the techniques necessary to obtain such

\footnotetext{
Abbreviations: AA, amino acid; M, maintenance energy.

* Corresponding author: Dr Simone O. Hoskin, present address, Institute of Food, Nutrition and Human Health, Massey University, Private Bag 11222, Palmerston North, New Zealand, fax +64 6 3505684, email S.O.Hoskin@massey.ac.nz
} 
knowledge are limited for situations in vivo, requiring either multiple sampling (Banos et al. 1973) or perfused preparations (Hundal et al. 1989). An alternative indirect approach was developed from traditional, trans-tissue, arterio-venous methods by Biolo et al. $(1992,1995)$ and involved a mathematical, three-compartment model that allowed both inward and outward transport of AA to be estimated. Based on this model, the relationships between transmembrane AA movements and rates of intracellular (tissue homogenate) protein metabolism were explored in a number of species, including human subjects, under various physiological and nutritional conditions (e.g. Biolo et al. 1992, 1994, 1995).

This model has been used in the current study to examine the effect of increasing feed intake, from less than to greater than maintenance energy $(\mathrm{M})$, on the dynamics of a number of AA across the tissues of the ovine hindquarters. In particular, the sensitivity of inward transport of AA and the potential limitation for either protein synthesis or protein retention was examined. Possible alternative constraints on protein metabolism, for example intracellular AA concentrations, were also investigated. Other components of the present study have been reported previously (Hoskin et al. 2001; Savary et al. 2001).

\section{Materials and methods}

\section{Animals and treatments}

Six Suffolk-cross wether lambs (aged 6-8 months, live weight $30 \cdot 5-34.5 \mathrm{~kg}$ ) were surgically prepared with hindlimb arterio-venous catheters according to the methods described by Savary et al. (2001). Permanent indwelling polyvinyl or silicone rubber catheters were inserted into the aorta (two, $30 \mathrm{~mm}$ apart; caudal for infusion of plasma flow marker $p$-aminohippurate and cranial for arterial blood sampling) and posterior vena cava (venous blood sampling), caudal to entry of the renal veins. As required, temporary polyvinyl catheters were inserted into the jugular vein (for labelled algal hydrolysate infusion), posterior vena cava via tarsal vein $(550-600 \mathrm{~mm}$; if permanent vena cava catheter lost patency) and auricular artery (arterial blood sample), or occasionally into the heart via jugular vein (mixed venous blood sample). The latter two options were used only if: (1) one of the aortal catheters lost patency; (2) if the auricular artery catheter failed.

The sheep were fed a pelleted dried grass diet (estimated metabolisable energy $10 \mathrm{MJ} / \mathrm{kg} \mathrm{DM}, 26 \mathrm{~g} \mathrm{~N} / \mathrm{kg} \mathrm{DM}$ ) from automatic feeders, supplied daily as twenty-four equal portions per $\mathrm{h}$, whilst housed in metabolism cages. In a Latinsquare design with two sequences repeated, the animals were offered each of four levels of feed intake corresponding to $0.5,1.0,1.5$ and $2.5 \times \mathrm{M}$ (based on daily $\mathrm{M}$ requirements of $400 \mathrm{~kJ} / \mathrm{kg}$ body weight ${ }^{075}$ ). Each level of intake was fed for 2 weeks prior to measurement, except for $0.5 \times$ $\mathrm{M}$, which was only fed during the week of measurement, with animals fed at $1.0 \times \mathrm{M}$ the week before measurement at $0.5 \times \mathrm{M}$. All animals consumed all the ration offered, and the $24 \mathrm{~h}$ portions were consumed immediately, except for two animals at the $2.5 \times \mathrm{M}$ intake level who were sometimes delayed by up to $1 \mathrm{~h}$ in consuming portions delivered between 02.00 and 06.00 hours.

During the week before measurement, animals were housed in metabolism cages. The rest of the time they were individually housed in floor pens with straw bedding and fed two times per d. Animals were kept under constant light cycle of $10 \mathrm{~h}$ light $-14 \mathrm{~h}$ dark, with free access to water and a multi-mineral salt block. All procedures involving animals were conducted according to Home Office (UK) requirements for animal ethics and welfare.

\section{Infusion, blood sampling and tissue biopsy}

Measurements of AA kinetics were made on the last day of each 2-week feeding period and involved infusion of a $\mathrm{U}-{ }^{13} \mathrm{C}$-labelled algal hydrolysate, prepared as described by Savary et al. (2001), based on Lobley et al. (1996). Samples of plasma were obtained on the day prior to infusion to provide background (natural abundance) samples for GC-MS analyses. The same amount of algal hydrolysate was continuously infused (20 g infusate/h; 22$198 \mu \mathrm{mol} \mathrm{AA} / \mathrm{h}$ ) into the jugular vein over a $10 \mathrm{~h}$ period, regardless of level of feed intake. Between 3 and $9 \mathrm{~h}$ a solution of $0.15 \mathrm{M}$-sodium $p$-aminohippurate, $\mathrm{pH} 7 \cdot 4,20 \mathrm{~g} / \mathrm{h}$ ) containing sodium heparin $(400 \mathrm{IU} / \mathrm{g})$ was infused into the more caudal aortal catheter to allow the determination of plasma flow. Integrated blood samples were withdrawn continuously by peristaltic pump from both the cranial aortal catheter (or auricular artery or heart) and the vena cava $(10 \mathrm{ml} / \mathrm{h}$ per catheter) over $30 \mathrm{~min}$ intervals during the last $4 \mathrm{~h}$ of $p$-aminohippurate infusion. The infusion of heparinised $p$-aminohippurate was discontinued after $9 \mathrm{~h}$, but the infusion of ${ }^{13} \mathrm{C}$-labelled AA was maintained. A small biopsy (about 200-400 mg) was taken $1 \mathrm{~h}$ later under local anaesthesia (Lignavet; C-Vet Veterinary Products, Leyland, Lancs., UK) from the skin and the underlying $m$. vastus lateralis of one leg. These tissue samples were rapidly cleaned of any fascia, fat and blood contamination, washed in ice-cold physiological saline $(9 \mathrm{~g} \mathrm{NaCl} /$ $\mathrm{kg}$ ), swabbed dry and then frozen in liquid $\mathrm{N}_{2}$, subsequent to storage at $-80^{\circ} \mathrm{C}$. Biopsies were taken from alternate legs for consecutive infusions. The two biopsies from each leg ( 4 weeks apart) were taken from sites approximately $100 \mathrm{~mm}$ apart. Spot arterial and venous blood samples were taken at approximately $30 \mathrm{~min}$ intervals from the end of $p$-aminohippurate infusion to immediately following the biopsy.

One concern included the possible effect of the local anaesthetic on AA transfers. This was tested in a companion study, where sheep infused with $\left[\mathrm{ring}-{ }_{-}^{2} \mathrm{H}_{5}\right]-$ phenylalanine were injected with the same local anaesthetic into a marked area of one leg, $15 \mathrm{~min}$ prior to terminal anaesthesia. Tissue-free phenylalanine enrichments were similar for tissue samples from either the site of local anaesthesia or a similar area of the other leg (SO Hoskin, IC Savary-Auzeloux and GE Lobley, unpublished results).

\section{Laboratory analyses}

Blood $(5 \mathrm{~g}$ ) was centrifuged for $10 \mathrm{~min}$ at $1000 \mathrm{~g}$, to obtain 
$3 \mathrm{~g}$ plasma. Plasma flow $(\mathrm{kg} / \mathrm{min}$ ) was determined from $1 \mathrm{~g}$ plasma according to the gravimetric method described by Lobley et al. (1996). To another $1 \mathrm{~g}$ plasma was added $0.3 \mathrm{~g}$ algal infusate solution (diluted $\times 2.5$ ) for measurement of AA concentration by the isotope-dilution technique using the $t$-butyldimethylsilyl derivatives (Calder et al. 1999). The remainder of plasma was stored in a microcentrifuge tube for later preparation of freeze-dried eluates (Savary et al. 2001). Enrichments of AA (as molar \% excess) were determined from freeze-dried eluates as $n$-butylheptafluorylbutryl derivatives, with the $\mathrm{D}$ and $\mathrm{L}$ proportions of lysine resolved on a chiral column (Lobley et al. 1996). Tissue biopsy samples were freezermilled (Spex 6700; Glen Creston, Stanmore, Middlesex, $\mathrm{UK}$ ) to a fine powder under liquid $\mathrm{N}_{2}$. These samples were then divided and prepared either for tissue enrichments (Connell et al. 1997) or for free AA concentrations (Rocha et al. 1993) measured on an AA analyser (Pharmacia-LKB Alpha Plus, Uppsala, Sweden), with post-column derivatisation with $o$-phthalylaldehyde and fluorescent detection.

A number of AA were not determined in either plasma and/or tissue for the following reasons. The derivitisation protocol adopted (Lobley et al. 1996) caused hydrolysis of glutamine and asparagine with consequent production of glutamate and aspartate and thus not all of these were analysed. During preparation of the algal hydrolysate, both cysteine and tryptophan are degraded and thus no flux values could be obtained. Methionine and alanine enrichments in the tissue samples were found to be unreliable due to the presence of unidentified interfering compounds.

\section{Calculations}

The model shown in Fig. 1 is based on Biolo et al. (1992, 1995). Let $F$ be the metabolite flow (concentration $X$ plasma flow) and $\mathrm{E}$ be metabolite enrichment. The term $\mathrm{F}_{\mathrm{yx}}$ represents the flow to pool $\mathrm{y}$ from pool $\mathrm{x}$. The subscripts $\mathrm{m}$, a, and $\mathrm{v}$ refer to the tissue homogenate, arterial and venous pools of free AA respectively, while o refers to the protein-bound $\mathrm{AA} . \mathrm{F}_{\text {in }}$ and $\mathrm{F}_{\text {out }}$ are the arterial inflows and venous outflows of AA respectively, and $F_{m a}$ and $F_{v m}$ reflect inward and outward transmembrane transport respectively. $\mathrm{F}_{\mathrm{mo}}$ represents appearance of AA from protein breakdown and de novo synthesis, whereas $\mathrm{F}_{\mathrm{om}}$ represents use of AA for protein synthesis, oxidation and other fates.

Assuming metabolic steady state, the steady-state equations of free AA for the arterial pool, venous pool and mixed tissue homogenate pool are given by:

$$
\begin{aligned}
& \mathrm{F}_{\text {in }}-\mathrm{F}_{\mathrm{va}}-\mathrm{F}_{\mathrm{ma}}=0, \\
& \mathrm{~F}_{\mathrm{va}}+\mathrm{F}_{\mathrm{vm}}-\mathrm{F}_{\mathrm{out}}=0,
\end{aligned}
$$

and

$$
\mathrm{F}_{\mathrm{ma}}+\mathrm{F}_{\mathrm{mo}}-\mathrm{F}_{\mathrm{om}}-\mathrm{F}_{\mathrm{vm}}=0 .
$$

It is assumed that steady state has also been achieved for the labelled AA and, furthermore, that no labelled AA is returned from protein breakdown. Then, the steady-state equations for the labelled AA for the venous pool and tissue homogenate pool are given by:

$$
\mathrm{E}_{\mathrm{a}} \mathrm{F}_{\mathrm{va}}+\mathrm{E}_{\mathrm{m}} \times \mathrm{F}_{\mathrm{vm}}-\mathrm{E}_{\mathrm{v}} \times \mathrm{F}_{\text {out }}=0
$$

and

$$
\mathrm{E}_{\mathrm{a}} \quad \mathrm{F}_{\mathrm{ma}}-\mathrm{E}_{\mathrm{m}} \times \mathrm{F}_{\mathrm{om}}-\mathrm{E}_{\mathrm{m}} \times \mathrm{F}_{\mathrm{vm}}=0,
$$

where $E_{a}, E_{m}$ and $E_{v}$ are the arterial, tissue homogenate and venous enrichments of labelled AA respectively.

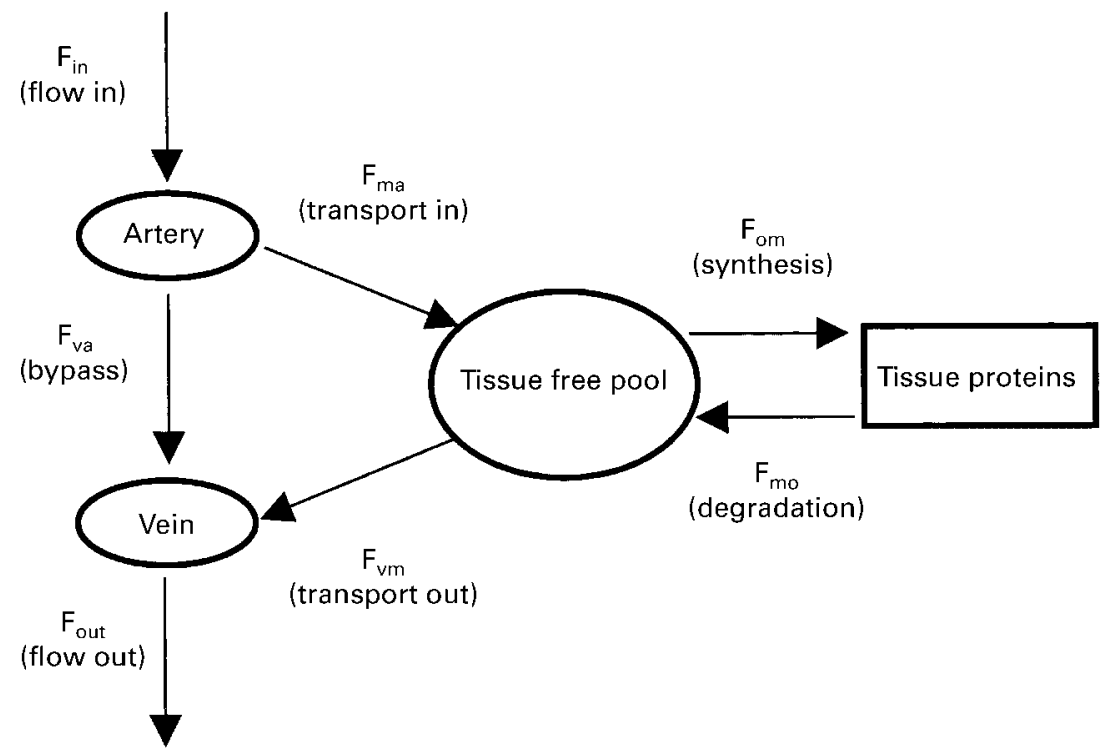

Fig. 1. The hindlimb kinetic model (based on Biolo et al. 1992, 1995). 
Combining (2) with (4) gives:

$$
F_{v m}=\frac{\mathrm{E}_{\mathrm{a}}-\mathrm{E}_{\mathrm{v}}}{\mathrm{E}_{\mathrm{a}}-\mathrm{E}_{\mathrm{m}}} \times \mathrm{F}_{\text {out }}
$$

The remaining flows are obtained from rearranging (2), (1), (5) and (3) respectively:

$$
\begin{gathered}
\mathrm{F}_{\mathrm{va}}=\mathrm{F}_{\mathrm{out}}-\mathrm{F}_{\mathrm{vm}}, \\
\mathrm{F}_{\mathrm{ma}}=\mathrm{F}_{\mathrm{in}}-\mathrm{F}_{\mathrm{va}}, \\
\mathrm{F}_{\mathrm{om}}=\frac{\mathrm{E}_{\mathrm{a}} \times \mathrm{F}_{\mathrm{ma}}-\mathrm{E}_{\mathrm{m}} \times \mathrm{F}_{\mathrm{vm}}}{\mathrm{E}_{\mathrm{m}}}
\end{gathered}
$$

and

$$
\mathrm{F}_{\mathrm{mo}}=\mathrm{F}_{\mathrm{om}}+\mathrm{F}_{\mathrm{vm}}-\mathrm{F}_{\mathrm{ma}} .
$$

\section{Assumptions and limitations of the model}

The various forms of the model developed by Biolo et al. (1992, 1995) all have the inherent assumption that the tissue homogenate pool represents a common precursor through which pass all inward (from AA influx and protein degradation) and outward transfers (AA efflux, protein synthesis and, where appropriate, AA synthesis de novo). While this assumption is difficult to test directly, nonetheless, the homogenate pool is probably the precursor for protein synthesis and AA oxidation in muscle for both pigs (Watt et al. 1992) and sheep (Lobley et al. 1992). In contrast, other tissues, such as skin, may rely more on direct use of extracellular AA for protein anabolism (Lobley et al. 1992). This complicates matters when the vascular drainage encompasses a mixture of tissues, as is the case for the hindquarter preparation, where muscle, skin, bone and fat will all contribute to the venous outflow. For such preparations, the correct approach would necessitate determination of both the blood flows and the respective metabolic activities for each tissue (Biolo et al. 1994) and then application of weighted average values to encompass the composite hindquarters. Another option is to measure the aminoacyl-tRNA for all AA within the various tissue biopsies. This would address possible differences between homogenate free AA enrichments and that of the precursor pool for protein synthesis (Caso et al. 2001); however, the half-lives of the aminoacyl-RNA are only a few seconds and values may alter during sampling and extraction. This may account for differences observed between various techniques (Lobley et al. 1992; Watt et al. 1992; Davis et al. 1999; Caso et al. 2001). In practice, none of these alternative approaches was feasible within the constraints of the present study and, therefore, it was assumed that the muscle biopsy values reflect the mean for the composite tissues.

Although the protein metabolic activity of skin, muscle and bone differ (e.g. Seve et al. 1986; Lobley et al. 1992; Ponter et al. 1994; Liu et al. 1998), the homogenate enrichments of skin and muscle were similar in the current study (see later), except for serine (skin $>$ muscle) and histidine (muscle $>$ skin). This approach has also been shown to be robust in other species, with similar trends between arterio-venous and direct incorporation techniques (Harris et al. 1992; Lobley et al. 1992; Zhang et al. 1998). No allowance was included for the contribution of extracellular fluid to the biopsy sample, but this is usually minor (Biolo et al. 1992).

\section{Statistics}

Comparisons were by ANOVA using Genstat 4.2 for Windows (Lawes Agricultural Trust, Rothamsted, Harpenden, Herts., UK). For main effects, animals were treated as blocks with period $\times$ intake as treatment. In all cases there was no effect of period and this was excluded. In a number of cases it was obvious that, at the three lower intakes, some kinetic variables were similar but changed markedly at the highest intake. For this reason, data were also analysed for both linear and quadratic effects, but were found to be predominantly linear, as found by Hoskin et al. (2001) with associated data.

\section{Results}

Results for blood flow, arterial concentrations and mass transfers across the hindlimb have been presented elsewhere (Hoskin et al. 2001; Savary et al. 2001). For ease of comparison, results are separated into three sections: the measured essential AA (histidine, lysine, phenylalanine and threonine, but excluding the branched-chain AA isoleucine, leucine and valine) and the measured nonessential AA (glycine, proline, serine and tyrosine).

\section{Amino acid supply and transport}

Absolute arterial plasma inflows $\left(\mathrm{F}_{\text {in }}\right)$ between AA varied 10 -fold (glycine and serine represented the extremes) in proportion to arterial concentrations. For most AA, $F_{\text {in }}$ increased with intake $(P<0 \cdot 01)$ and with strong linear responses $(P<0.01$; Tables 1,2 and 3$)$. The exception was glycine, where only the linear response was significant $(P=0.028)$. This was due to the large increase for $2.5 \times \mathrm{M}$ compared with the other three intakes (Table 3 ). For multitreatment comparisons, ANOVA is not efficient at separating relatively small changes in one group when the remaining groups are similar. The linear regression analysis compares weighted means of the lower two and upper two intakes and thus includes a greater emphasis on comparison between the extreme intakes. The observed changes in $F_{i n}$ at the lower intakes were mainly related to increased AA plasma concentrations, but at the highest intake a combination of increased concentration (SavaryAuzeloux et al. 2002) and greater blood flow (Hoskin et al. 2001) occurred. For most AA, the larger inflow to the hindquarters was accompanied by a greater outflow in the venous drainage $\left(\mathrm{F}_{\text {out }}, P<0.05\right.$ or better $)$. The exceptions were histidine and glycine, but even for these the linear responses remained significant $(P<0 \cdot 05)$.

$F_{\text {in }}$ is distributed between entry to the tissues and vascular bypass. The proportion of $\mathrm{F}_{\text {in }}$ transported into the tissues varied: $0.4-0.5$ for isoleucine, leucine, phenylalanine and serine; $0.3-0.4$ for lysine and threonine; 
Table 1. Effect of feed intake on hindlimb histidine, lysine, phenylalanine and threonine arterial $\left(F_{i n}\right)$, venous $\left(F_{\text {out }}\right)$ and bypass $\left(F_{v a}\right)$ flows, transport from the artery to the 'muscle' free pool $\left(F_{m a}\right)$ and from the 'muscle' free pool to the vein $\left(F_{\mathrm{vm}}\right)$, protein synthesis $\left(F_{\mathrm{om}}\right)$ and degradation $\left(F_{\mathrm{mo}}\right)^{*}$

(Mean values for six sheep at each feed intake)

\begin{tabular}{|c|c|c|c|c|c|c|c|}
\hline \multirow[b]{2}{*}{ Amino acid $(\mu \mathrm{mol} / \mathrm{min})$} & \multicolumn{4}{|c|}{ Feed intake } & \multicolumn{2}{|c|}{$\begin{array}{l}\text { Statistical signifi- } \\
\text { cance of effect } \\
\text { (ANOVA): } P+\end{array}$} & \multirow[b]{2}{*}{ SED } \\
\hline & $0.5 \times M$ & $1.0 \times M$ & $1.5 \times M$ & $2.5 \times M$ & Intake & Linear & \\
\hline \multicolumn{8}{|l|}{ Histidine } \\
\hline $\mathrm{F}_{\text {in }}$ & $26 \cdot 9$ & $28 \cdot 7$ & $31 \cdot 7$ & $42 \cdot 1$ & 0.029 & 0.004 & $4 \cdot 78$ \\
\hline $\mathrm{F}_{\text {out }}$ & $27 \cdot 7$ & $28 \cdot 3$ & $31 \cdot 1$ & $39 \cdot 7$ & NS & 0.019 & 4.94 \\
\hline $\mathrm{F}_{\mathrm{ma}}$ & 3.5 & $3 \cdot 6$ & $4 \cdot 0$ & $6 \cdot 1$ & 0.017 & 0.003 & 0.79 \\
\hline $\mathrm{F}_{\mathrm{vm}}$ & $4 \cdot 3$ & $3 \cdot 3$ & 3.4 & 3.7 & NS & & 0.85 \\
\hline $\mathrm{F}_{\mathrm{va}}$ & 23.4 & $25 \cdot 1$ & $27 \cdot 7$ & $36 \cdot 0$ & 0.047 & 0.007 & $4 \cdot 28$ \\
\hline $\mathrm{F}_{\mathrm{om}}$ & $63 \cdot 2$ & $50 \cdot 3$ & $56 \cdot 6$ & $70 \cdot 8$ & NS & & 14.43 \\
\hline $\mathrm{F}_{\mathrm{mo}}$ & $64 \cdot 0$ & $50 \cdot 0$ & $56 \cdot 0$ & $68 \cdot 4$ & NS & & 14.40 \\
\hline \multicolumn{8}{|l|}{ Lysine } \\
\hline$F_{\text {in }}$ & $36 \cdot 8$ & $47 \cdot 5$ & $56 \cdot 1$ & $74 \cdot 4$ & 0.011 & 0.001 & 9.45 \\
\hline$F_{\text {out }}$ & $37 \cdot 6$ & $45 \cdot 7$ & $52 \cdot 8$ & $66 \cdot 6$ & 0.048 & 0.007 & $9 \cdot 34$ \\
\hline $\mathrm{F}_{\mathrm{ma}}$ & $13 \cdot 0$ & $14 \cdot 2$ & $16 \cdot 5$ & $28 \cdot 9$ & $<0.001$ & $<0.001$ & $3 \cdot 11$ \\
\hline $\mathrm{F}_{\mathrm{vm}}$ & $13 \cdot 8$ & $12 \cdot 4$ & $13 \cdot 3$ & $21 \cdot 1$ & 0.056 & 0.020 & $3 \cdot 13$ \\
\hline $\mathrm{F}_{\mathrm{va}}$ & $23 \cdot 8$ & $33 \cdot 3$ & 39.6 & 45.5 & 0.079 & 0.015 & $7 \cdot 79$ \\
\hline$F_{\text {om }}$ & $28 \cdot 8$ & $25 \cdot 0$ & 35.6 & $30 \cdot 6$ & NS & & $8 \cdot 15$ \\
\hline $\mathrm{F}_{\mathrm{mo}}$ & $29 \cdot 6$ & $23 \cdot 2$ & $32 \cdot 4$ & $22 \cdot 8$ & NS & & $8 \cdot 38$ \\
\hline \multicolumn{8}{|l|}{ Phenylalanine } \\
\hline $\mathrm{F}_{\text {in }}$ & $22 \cdot 8$ & $25 \cdot 3$ & 31.4 & $60 \cdot 2$ & 0.002 & $<0.001$ & $7 \cdot 80$ \\
\hline$F_{\text {out }}$ & 23.9 & $25 \cdot 2$ & 31.5 & $58 \cdot 3$ & 0.003 & $<0.001$ & $7 \cdot 91$ \\
\hline $\mathrm{F}_{\mathrm{ma}}$ & $10 \cdot 9$ & $10 \cdot 9$ & $12 \cdot 0$ & $22 \cdot 1$ & 0.037 & 0.009 & 4.56 \\
\hline $\mathrm{F}_{\mathrm{vm}}$ & $12 \cdot 1$ & $10 \cdot 8$ & $12 \cdot 0$ & $22 \cdot 1$ & 0.096 & 0.030 & 4.57 \\
\hline $\mathrm{F}_{\mathrm{va}}$ & 11.9 & $14 \cdot 3$ & 19.5 & $36 \cdot 2$ & 0.002 & $<0.001$ & 4.96 \\
\hline $\mathrm{F}_{\mathrm{om}}$ & $10 \cdot 5$ & $9 \cdot 2$ & $16 \cdot 4$ & $10 \cdot 1$ & NS & & 3.58 \\
\hline $\mathrm{F}_{\mathrm{mo}}$ & $11 \cdot 6$ & $9 \cdot 1$ & $16 \cdot 4$ & $8 \cdot 1$ & NS & & 3.76 \\
\hline \multicolumn{8}{|l|}{ Threonine } \\
\hline$F_{\text {in }}$ & 33.4 & $51 \cdot 8$ & $62 \cdot 3$ & $99 \cdot 8$ & $<0.001$ & $<0.001$ & $12 \cdot 06$ \\
\hline$F_{\text {out }}$ & 34.9 & $51 \cdot 2$ & $60 \cdot 6$ & 95.6 & 0.001 & $<0.001$ & 11.86 \\
\hline $\mathrm{F}_{\mathrm{ma}}$ & 12.9 & $15 \cdot 5$ & 18.5 & $32 \cdot 8$ & $<0.001$ & $<0.001$ & 3.98 \\
\hline $\mathrm{F}_{\mathrm{vm}}$ & 14.4 & 14.9 & $16 \cdot 9$ & $28 \cdot 6$ & 0.011 & 0.002 & 4.03 \\
\hline $\mathrm{F}_{\mathrm{va}}$ & 20.5 & $36 \cdot 3$ & 43.7 & $67 \cdot 1$ & 0.003 & $<0.001$ & 9.89 \\
\hline $\mathrm{F}_{\mathrm{om}}$ & $18 \cdot 4$ & $19 \cdot 2$ & $26 \cdot 7$ & $32 \cdot 8$ & 0.005 & $<0.001$ & 3.71 \\
\hline$F_{m o}$ & $19 \cdot 8$ & $18 \cdot 6$ & $25 \cdot 0$ & $28 \cdot 7$ & NS & 0.033 & 4.45 \\
\hline
\end{tabular}

$M$, maintenance energy.

* For details of diets and procedures, see p. 168

†The expected d.f. were 15, but there were some missing values: histidine and theonine d.f. 14, lysine d.f. 13, phenylalanine d.f. 12.

$0 \cdot 2-0 \cdot 3$ for glycine, proline, tyrosine and valine; $0 \cdot 13$ for histidine. This partition of $F_{\text {in }}$ was not altered by intake for most AA, although for tyrosine $(P<0.02)$ a lesser fraction $(0 \cdot 22$ compared with $0 \cdot 40)$ was transported into tissues as intake increased.

Absolute rates of tissue entry ( $F_{\text {ma }}$, mass/time) again varied more than 10-fold between AA, with the lowest values for histidine and the highest for glycine. For the essential AA, branched-chain AA and serine, $F_{m a}$ increased with intake $(P<0.05$ or better $)$ and with linear effects $(P<0.01$ or better, except for isoleucine $P=0.022)$. Inward transport of proline showed a linear trend $(P=0.013)$, but neither glycine nor tyrosine were altered by intake. The linear contrasts of the ANOVA involve comparison between the two lower and the two higher intakes. Where linear effects were observed, but in the absence of significant responses from conventional ANOVA, these were invariably due to the large changes observed at the highest $(2.5 \times \mathrm{M})$ intake. Apparent net retention of individual AA across the hindquarters has been reported elsewhere (Hoskin et al. 2001), but can be obtained as the difference between $F_{\text {in }}$ and $F_{\text {out }}$.

\section{Protein synthesis and retention}

If there is no oxidation of the AA, or transformation to other metabolites, then apparent net retention should truly represent protein gain. This will be the case for histidine, lysine, phenylalanine, threonine and tyrosine. The proportion of inward flow $\left(\mathrm{F}_{\mathrm{ma}}\right)$ used to support apparent AA retention by the tissues varied with intake for all AA $(P<0.02$ or better $)$, except for glycine and serine. These comparisons included the negative values obtained at $0.5 \times$ $M$, when the hindquarter tissues underwent net protein mobilisation and the sheep were losing body weight (Hoskin et al. 2001). At the highest intake, the proportion of inward transport retained on a net basis varied between $0 \cdot 1-0 \cdot 2$ for phenylalanine, threonine and tyrosine; $0 \cdot 2-0 \cdot 3$ for isoleucine, leucine, lysine and valine; 0.32 for proline; 0.43 for histidine. AA effluxes $\left(F_{\mathrm{vm}}\right)$ from the hindlimb 
Table 2. Effect of feed intake on hindlimb branched-chain amino acid arterial $\left(F_{\text {in }}\right)$ venous $\left(F_{\text {out }}\right)$, and bypass $\left(F_{v a}\right)$ flows, transport from the artery to the 'muscle' free pool $\left(F_{\mathrm{ma}}\right)$ and from the 'muscle' free pool to the vein $\left(F_{\mathrm{vm}}\right)$, protein synthesis $\left(\mathrm{F}_{\mathrm{om}}\right)$ and degradation $\left(\mathrm{F}_{\mathrm{mo}}\right)^{*}$

(Mean values for six sheep at each feed intake)

\begin{tabular}{|c|c|c|c|c|c|c|c|}
\hline \multirow[b]{2}{*}{ Amino acid ( $\mu \mathrm{mol} / \mathrm{min})$} & \multicolumn{4}{|c|}{ Feed intake } & \multicolumn{2}{|c|}{$\begin{array}{l}\text { Statistical signifi- } \\
\text { cance of effect } \\
\text { (ANOVA): } P \dagger\end{array}$} & \multirow[b]{2}{*}{ SED } \\
\hline & $0.5 \times M$ & $1.0 \times M$ & $1.5 \times M$ & $2.5 \times M$ & Intake & Linear & \\
\hline \multicolumn{8}{|l|}{ Isoleucine } \\
\hline$F_{\text {in }}$ & 30.5 & $40 \cdot 9$ & $46 \cdot 8$ & $106 \cdot 6$ & $<0.001$ & $<0.001$ & 7.82 \\
\hline$F_{\text {out }}$ & $30 \cdot 8$ & 38.5 & $44 \cdot 1$ & $97 \cdot 8$ & $<0.001$ & $<0.001$ & 7.58 \\
\hline $\mathrm{F}_{\mathrm{ma}}$ & $12 \cdot 6$ & 34.8 & $12 \cdot 4$ & 54.5 & 0.032 & 0.022 & 13.92 \\
\hline $\mathrm{F}_{\mathrm{vm}}$ & $12 \cdot 9$ & $32 \cdot 4$ & $9 \cdot 8$ & $45 \cdot 7$ & 0.071 & 0.064 & $13 \cdot 60$ \\
\hline $\mathrm{F}_{\mathrm{va}}$ & $17 \cdot 9$ & $6 \cdot 1$ & 34.3 & $52 \cdot 1$ & 0.024 & 0.007 & 13.07 \\
\hline $\mathrm{F}_{\mathrm{om}}$ & 13.2 & $11 \cdot 3$ & $16 \cdot 0$ & $34 \cdot 7$ & 0.030 & 0.007 & $7 \cdot 28$ \\
\hline $\mathrm{F}_{\mathrm{mo}}$ & $13 \cdot 5$ & 8.9 & $13 \cdot 4$ & $25 \cdot 9$ & NS & 0.059 & $7 \cdot 13$ \\
\hline \multicolumn{8}{|l|}{ Leucine } \\
\hline$F_{\text {in }}$ & $50 \cdot 9$ & 59.9 & $81 \cdot 1$ & $158 \cdot 9$ & $<0.001$ & $<0.001$ & $15 \cdot 62$ \\
\hline$F_{\text {out }}$ & 51.5 & 56.5 & $75 \cdot 8$ & $145 \cdot 4$ & $<0.001$ & $<0.001$ & $15 \cdot 13$ \\
\hline$F_{m a}$ & $25 \cdot 3$ & $35 \cdot 0$ & $37 \cdot 8$ & $63 \cdot 8$ & 0.013 & 0.002 & $10 \cdot 08$ \\
\hline $\mathrm{F}_{\mathrm{vm}}$ & $25 \cdot 9$ & 31.6 & 32.5 & $50 \cdot 3$ & NS & 0.020 & 9.45 \\
\hline $\mathrm{F}_{\mathrm{va}}$ & $25 \cdot 6$ & $25 \cdot 0$ & $43 \cdot 3$ & 95.1 & $<0.001$ & $<0.001$ & 10.56 \\
\hline $\mathrm{F}_{\mathrm{om}}$ & $26 \cdot 0$ & $25 \cdot 3$ & $31 \cdot 1$ & $60 \cdot 6$ & $<0.001$ & $<0.001$ & 4.82 \\
\hline$F_{\mathrm{mo}}$ & $26 \cdot 6$ & 21.9 & $25 \cdot 8$ & $47 \cdot 1$ & $<0.001$ & $<0.001$ & 4.96 \\
\hline \multicolumn{8}{|l|}{ Valine } \\
\hline$F_{\text {in }}$ & 68.5 & $102 \cdot 1$ & $150 \cdot 4$ & 280.9 & $<0.001$ & $<0.001$ & $26 \cdot 11$ \\
\hline$F_{\text {out }}$ & $69 \cdot 1$ & $99 \cdot 9$ & $146 \cdot 5$ & $270 \cdot 2$ & $<0.001$ & $<0.001$ & $25 \cdot 77$ \\
\hline$F_{m a}$ & $23 \cdot 0$ & $23 \cdot 8$ & $29 \cdot 3$ & $53 \cdot 6$ & 0.015 & 0.003 & 9.01 \\
\hline$F_{v m}$ & $23 \cdot 6$ & 21.6 & $25 \cdot 3$ & $42 \cdot 9$ & NS & 0.032 & 9.07 \\
\hline $\mathrm{F}_{\mathrm{va}}$ & $45 \cdot 5$ & $78 \cdot 3$ & $121 \cdot 2$ & $227 \cdot 3$ & $<0.001$ & $<0.001$ & 23.25 \\
\hline $\mathrm{F}_{\mathrm{om}}$ & $17 \cdot 1$ & $16 \cdot 7$ & $25 \cdot 5$ & 54.8 & 0.013 & 0.02 & 11.03 \\
\hline $\mathrm{F}_{\mathrm{mo}}$ & $17 \cdot 7$ & 14.4 & 21.6 & $44 \cdot 1$ & 0.068 & 0.017 & 10.95 \\
\hline
\end{tabular}

M, maintenance energy.

* For details of diets and procedures, see p. 168.

†The expected d.f. were 15, but there were some missing values: isoleucine d.f. 11, leucine and valine d.f. 13.

tissues showed weaker trends in response to intake and were only significant for threonine and serine. In addition, linear responses were also observed for leucine, lysine, phenylalanine and valine.

Isoleucine, leucine, threonine and valine all showed increases in $\mathrm{F}_{\text {om }}$ (protein synthesis plus oxidation; Tables 1 and 2) in response to higher intakes $(P=0.03$ or better). Protein degradation $\left(\mathrm{F}_{\mathrm{mo}}\right)$ increased with intake only for leucine $(P<0.01)$, but with a linear response also for threonine and valine $(P<0 \cdot 05)$. The combination of $\mathrm{F}_{\mathrm{ma}}$ (inward transport) and $\mathrm{F}_{\mathrm{mo}}$ (proteolysis and any AA synthesis de novo) gives the total flow through the homogenate pool (as does $\mathrm{F}_{\mathrm{vm}}$ plus $\mathrm{F}_{\mathrm{om}}$ ). This total flow was sensitive to intake for the branched-chain AA and threonine $(P<0.03$ or better $)$, with additional linear trends for phenylalanine, serine and tyrosine. There were marked differences between the AA in the relative inflows from either $\mathrm{F}_{\mathrm{ma}}$ or $\mathrm{F}_{\mathrm{mo}}$. The contributions from inward transport $\left(\mathrm{F}_{\mathrm{ma}}\right)$ were: branched-chain AA plus glycine and phenylalanine $0.5-0.6$; lysine, threonine and tyrosine $0.4-0.5$; proline and serine $0.2-0.3$; histidine 0.07 . This proportional contribution was sensitive to intake only for histidine $(P<0.03)$, but with linear trends for lysine, phenylalanine, serine and threonine $(P<0.05$ or better). The proportion of inward transport used for $\mathrm{F}_{\mathrm{om}}$ (synthesis and oxidation) was insensitive to intake (except for a linear trend for histidine, $P<0.02)$. For several AA the use (apparent disposal) of inward transport $\left(\mathrm{F}_{\mathrm{ma}}\right)$ for synthetic and oxidative purposes approached unity (glycine, isoleucine, leucine, phenylalanine, threonine and valine). For the other AA, apparent disposal exceeded inward transport by $2-4$-fold, except for histidine, where inward transport from plasma only accounted for $0 \cdot 1-0.2$ of the needs for protein synthesis. In terms of total inflow to the homogenate pool (i.e. $\left.\mathrm{F}_{\mathrm{ma}}+\mathrm{F}_{\mathrm{mo}}\right)$, disposal $\left(\mathrm{F}_{\mathrm{om}}\right)$ accounted for 0.39-0.66 for most AA, except for histidine, proline and serine where values ranged from 0.79 to 0.94 .

\section{Tissue amino acid concentrations and enrichments}

Responses to intake in muscle biopsy AA concentrations were of three types. Some AA (glycine, isoleucine, leucine, phenylalanine and serine) remained unaltered (Table 4). Of these, the essential and branched-chain AA forms had concentrations (mM) lower than for arterial plasma, while glycine and serine were concentrated approximately 3.0fold within the muscle. Concentrations of some AA declined as intake increased (histidine and lysine; Table 4). Across the intake range, histidine remained concentrated in muscle by approximately $1 \cdot 5-2 \cdot 5$-fold, while lysine decreased from double that of arterial plasma at the lowest intake to similar values at the higher intakes. The remainder of the AA (threonine, tyrosine and valine) increased tissue concentrations as intake was raised. 
Table 3. Effect of feed intake on hindlimb nonessential amino acid arterial $\left(F_{\text {in }}\right)$, venous $\left(F_{\text {out }}\right)$, and bypass $\left(F_{v a}\right)$ flows, transport from the artery to the 'muscle' free pool $\left(F_{\mathrm{ma}}\right)$ and from the 'muscle' free pool to the vein $\left(F_{v m}\right)$, protein synthesis $\left(F_{o m}\right)$ and degradation $\left(F_{m o}\right)^{*}$ (Mean values for six sheep at each feed intake)

\begin{tabular}{|c|c|c|c|c|c|c|c|}
\hline \multirow{2}{*}{ Amino acid ( $\mu \mathrm{mol} / \mathrm{min})$} & \multicolumn{4}{|c|}{ Feed intake } & \multicolumn{2}{|c|}{$\begin{array}{l}\text { Statistical signifi- } \\
\text { cance of effect } \\
\text { (ANOVA): P† }\end{array}$} & \multirow[b]{2}{*}{ SED } \\
\hline & $0.5 \times M$ & $1.0 \times M$ & $1.5 \times M$ & $2.5 \times M$ & Intake & Linear & \\
\hline \multicolumn{8}{|l|}{ Glycine } \\
\hline$F_{\text {in }}$ & 216 & 216 & 217 & 302 & NS & 0.028 & $37 \cdot 5$ \\
\hline $\mathrm{F}_{\text {out }}$ & 219 & 219 & 221 & 306 & 0.087 & 0.025 & 37.5 \\
\hline $\mathrm{F}_{\text {ma }}$ & $59 \cdot 1$ & $52 \cdot 0$ & $53 \cdot 8$ & $80 \cdot 0$ & NS & & 14.02 \\
\hline $\mathrm{F}_{\mathrm{vm}}$ & $61 \cdot 8$ & $54 \cdot 5$ & $57 \cdot 8$ & $84 \cdot 6$ & NS & 0.063 & $13 \cdot 17$ \\
\hline $\mathrm{F}_{\mathrm{va}}$ & 157 & 164 & 163 & 222 & NS & 0.037 & 29.5 \\
\hline $\mathrm{F}_{\mathrm{om}}$ & $45 \cdot 5$ & $35 \cdot 2$ & $42 \cdot 7$ & $52 \cdot 6$ & NS & & $12 \cdot 44$ \\
\hline $\mathrm{F}_{\mathrm{mo}}$ & $48 \cdot 2$ & $37 \cdot 1$ & $46 \cdot 7$ & $57 \cdot 0$ & NS & & $10 \cdot 84$ \\
\hline \multicolumn{8}{|l|}{ Proline } \\
\hline $\mathrm{F}_{\text {in }}$ & $28 \cdot 5$ & $33 \cdot 0$ & $41 \cdot 3$ & $60 \cdot 5$ & 0.002 & $<0.001$ & 6.97 \\
\hline $\mathrm{F}_{\text {out }}$ & $29 \cdot 2$ & $32 \cdot 3$ & $39 \cdot 8$ & $57 \cdot 0$ & 0.005 & $<0.001$ & 6.85 \\
\hline$F_{m a}$ & $6 \cdot 1$ & $7 \cdot 6$ & $8 \cdot 3$ & $11 \cdot 8$ & 0.081 & 0.013 & 2.06 \\
\hline $\mathrm{F}_{\mathrm{vm}}$ & $6 \cdot 7$ & $6 \cdot 8$ & $6 \cdot 8$ & 8.4 & NS & & 1.93 \\
\hline $\mathrm{F}_{\mathrm{va}}$ & $22 \cdot 5$ & 25.5 & 33.0 & $48 \cdot 7$ & 0.003 & $<0.001$ & 5.98 \\
\hline $\mathrm{F}_{\mathrm{om}}$ & $30 \cdot 0$ & $25 \cdot 3$ & 28.9 & 38.3 & NS & & $7 \cdot 29$ \\
\hline $\mathrm{F}_{\mathrm{mo}}$ & 30.6 & $24 \cdot 6$ & 27.5 & 34.9 & NS & & $7 \cdot 18$ \\
\hline \multicolumn{8}{|l|}{ Serine } \\
\hline$F_{\text {in }}$ & $15 \cdot 2$ & 21.4 & 25.9 & $42 \cdot 8$ & $<0.001$ & $<0.001$ & 4.97 \\
\hline$F_{\text {out }}$ & $15 \cdot 1$ & $19 \cdot 2$ & 23.9 & $36 \cdot 6$ & 0.001 & $<0.001$ & 4.41 \\
\hline$F_{m a}$ & $7 \cdot 4$ & 9.9 & $11 \cdot 8$ & $20 \cdot 4$ & 0.001 & $<0.001$ & $2 \cdot 62$ \\
\hline $\mathrm{F}_{\mathrm{vm}}$ & $7 \cdot 3$ & $7 \cdot 7$ & 9.8 & $14 \cdot 3$ & 0.022 & 0.003 & $2 \cdot 15$ \\
\hline $\mathrm{F}_{\mathrm{va}}$ & $7 \cdot 8$ & 11.5 & $14 \cdot 1$ & 22.4 & 0.004 & $<0.001$ & 3.30 \\
\hline $\mathrm{F}_{\mathrm{om}}$ & 40.7 & 34.4 & $42 \cdot 4$ & $54 \cdot 6$ & NS & & $10 \cdot 36$ \\
\hline $\mathrm{F}_{\mathrm{mo}}$ & $40 \cdot 6$ & $32 \cdot 2$ & $40 \cdot 4$ & 48.5 & NS & & $10 \cdot 50$ \\
\hline \multicolumn{8}{|l|}{ Tyrosine } \\
\hline$F_{\text {in }}$ & $17 \cdot 1$ & $23 \cdot 8$ & $30 \cdot 4$ & $60 \cdot 2$ & $<0.001$ & $<0.001$ & 5.90 \\
\hline$F_{\text {out }}$ & 17.9 & $24 \cdot 0$ & $30 \cdot 8$ & $60 \cdot 1$ & $<0.001$ & $<0.001$ & 5.99 \\
\hline $\mathrm{F}_{\mathrm{ma}}$ & $6 \cdot 8$ & $8 \cdot 3$ & $8 \cdot 2$ & $10 \cdot 2$ & NS & & 2.04 \\
\hline $\mathrm{F}_{\mathrm{vm}}$ & $7 \cdot 6$ & 8.5 & 8.5 & $10 \cdot 0$ & NS & & $2 \cdot 18$ \\
\hline $\mathrm{F}_{\mathrm{va}}$ & $10 \cdot 3$ & $15 \cdot 5$ & $22 \cdot 3$ & $50 \cdot 0$ & $<0.001$ & $<0.001$ & $5 \cdot 14$ \\
\hline $\mathrm{F}_{\mathrm{om}}$ & 9.8 & 9.5 & $19 \cdot 1$ & 21.5 & NS & 0.062 & $6 \cdot 74$ \\
\hline $\mathrm{F}_{\mathrm{mo}}$ & $10 \cdot 6$ & 9.7 & $19 \cdot 4$ & $21 \cdot 3$ & NS & 0.075 & $6 \cdot 67$ \\
\hline
\end{tabular}

$M$, maintenance energy.

* For details of diets and procedures, see p. 168.

†The expected d.f. were 15, but there were some missing values: glycine, proline and serine d.f. 14, tyrosine d.f. 13 .

Threonine was concentrated $2 \cdot 0$-fold with regard to arterial concentrations, whilst tyrosine and valine were either lower or similar to plasma. Across increasing intakes, the muscle:arterial plasma concentrations did not vary significantly except for lysine, serine and valine where the value of the ratio declined, particularly between $0.5 \times \mathrm{M}$ and $1.0 \times \mathrm{M}$ (Table 5). In skin, the concentrations of branched-chain AA, phenylalanine and glycine were all raised by increasing intake (Table 4 ), whilst the remaining AA were unchanged. There were no intake-related effects on the skin:arterial plasma concentration ratios. Similarly, the muscle:skin AA concentrations were not altered significantly by level of intake, except for lysine $(P<0.02)$ where the value of the ratio declined. Overall, the enrichments of most AA in muscle were equal to or exceeded those in skin, with the value of the ratio between 1.0 and 1.5 , except for histidine $(0.14)$, proline $(0.51)$ and serine (3.54). The value of the ratio of enrichments between the tissues was unaffected by intake.

\section{Discussion}

This present study was based on two questions, which are not considered to be mutually exclusive: 'Is transport of AA into cells sensitive to food intake?'; 'Does transport of AA into cells of hindquarter tissues limit their ability to either synthesise or accrete protein?'. If the answer to the second question was 'yes', then approaches to enhance either transporter number or activity become attractive.

\section{Intake, tissue amino acid supply and uptake}

While intake can influence both arterial concentrations of AA and total blood flow to muscle, it has been difficult to explain responses (protein synthesis or accretion) in terms of these two variables alone (Lescoat et al. 1996). This is also shown in Fig. 2(a), in which regression analysis of the combined results for three AA are shown. The relationship between $F_{\text {in }}$ and net retention is low $(<0 \cdot 18)$ 
Table 4. Effect of feed intake ( $\times$ maintenance energy) on homogenate muscle ( $m$. vastis lateralis) and skin amino acid concentrations*

(Mean values for six sheep at each feed intake)

\begin{tabular}{|c|c|c|c|c|c|c|c|}
\hline \multirow[b]{2}{*}{ Amino acid $(\mu \mathrm{mol} / \mathrm{kg})$} & \multicolumn{4}{|c|}{ Feed intake } & \multicolumn{2}{|c|}{$\begin{array}{l}\text { Statistical signifi- } \\
\text { cance of effect } \\
\text { (ANOVA): } P \dagger\end{array}$} & \multirow[b]{2}{*}{ SED } \\
\hline & $0.5 \times M$ & $1.0 \times M$ & $1.5 \times M$ & $2.5 \times M$ & Intake & Linear & \\
\hline \multicolumn{8}{|l|}{ Muscle } \\
\hline Glycine & 1268 & 1045 & 1220 & 1162 & NS & & $253 \cdot 3$ \\
\hline Histidine & 122 & 95 & 107 & 88 & 0.065 & 0.036 & $12 \cdot 2$ \\
\hline Isoleucine & 39 & 34 & 34 & 45 & NS & & $5 \cdot 8$ \\
\hline Leucine & 77 & 64 & 61 & 83 & NS & & $9 \cdot 9$ \\
\hline Lysine & 127 & 74 & 82 & 52 & 0.057 & 0.017 & $25 \cdot 3$ \\
\hline Phenylalanine & 34 & 31 & 29 & 38 & NS & & 5.4 \\
\hline Serine & 193 & 131 & 135 & 127 & NS & & $32 \cdot 2$ \\
\hline Threonine & 175 & 192 & 209 & 279 & 0.035 & 0.005 & 33.5 \\
\hline Tyrosine & 33 & 34 & 34 & 47 & 0.007 & 0.002 & 3.9 \\
\hline Valine & 107 & 102 & 103 & 158 & 0.003 & 0.001 & $14 \cdot 0$ \\
\hline \multicolumn{8}{|l|}{ Skin } \\
\hline Glycine & 861 & 1262 & 1028 & 1401 & 0.035 & 0.020 & $174 \cdot 0$ \\
\hline Histidine & 70 & 79 & 66 & 83 & NS & & 11.8 \\
\hline Isoleucine & 40 & 45 & 44 & 79 & 0.001 & $<0.001$ & 8.4 \\
\hline Leucine & 88 & 85 & 76 & 135 & 0.020 & 0.012 & $17 \cdot 6$ \\
\hline Lysine & 65 & 64 & 58 & 80 & NS & & 9.6 \\
\hline Phenylalanine & 48 & 59 & 49 & 81 & 0.089 & 0.031 & 13.5 \\
\hline Serine & 312 & 394 & 389 & 748 & NS & & $178 \cdot 2$ \\
\hline Threonine & 129 & 157 & 146 & 211 & NS & & $33 \cdot 6$ \\
\hline Tyrosine & $50 \cdot 8$ & $69 \cdot 4$ & $59 \cdot 3$ & $68 \cdot 0$ & NS & & $9 \cdot 31$ \\
\hline Valine & 138 & 154 & 150 & 264 & 0.001 & $<0.001$ & $27 \cdot 6$ \\
\hline
\end{tabular}

$M$, maintenance energy.

${ }^{*}$ For details of diets and procedures, see p. 168.

†d.f. 15.

and with only a moderate correlation $\left(R^{2} 0.73\right)$. Such poor correlations may be due, in part, to the fact that not all inflow to an organ is either available to, or exchanges with, the cells. In the mammary gland, for example, flow through individual capillaries is not constant and changes with time (Prosser et al. 1996). Thus, the temporal pattern of nutrient supply to different parts of the udder varies and the concept of 'nutritive' flow was introduced to include only the quantity that perfuses 'active' parts of the tissue and exchanges with the cells (Prosser et al. 1996).

This regionalisation of blood flow would, of necessity, also involve 'non-nutritive', or 'bypass', flow via anastomose or 'shunt' vessels, as measured by $\mathrm{F}_{\mathrm{va}}$ in the current study. At its simplest, the theory would propose that blood

Table 5. Free amino acids in muscle ( $m$. vastis lateralis) water:free amino acids in arterial plasma water ratios ${ }^{*} \dagger$

(Mean values for six sheep at each feed intake)

\begin{tabular}{|c|c|c|c|c|c|c|c|}
\hline \multirow[b]{2}{*}{ Amino acid } & \multicolumn{4}{|c|}{ Feed intake } & \multicolumn{2}{|c|}{$\begin{array}{l}\text { Statistical signifi- } \\
\text { cance of effect } \\
\text { (ANOVA): P¥ }\end{array}$} & \multirow[b]{2}{*}{ SED } \\
\hline & $0.5 \times M$ & $1.0 \times M$ & $1.5 \times M$ & $2.5 \times M$ & Intake & Linear & \\
\hline Glycine & 4.03 & 3.40 & 3.73 & 4.01 & NS & & 1.347 \\
\hline Histidine & 2.65 & $2 \cdot 10$ & $2 \cdot 31$ & $1 \cdot 81$ & NS & 0.058 & 0.362 \\
\hline Isoleucine & 0.78 & 0.62 & 0.48 & 0.38 & NS & 0.041 & 0.177 \\
\hline Leucine & 0.84 & 0.75 & 0.52 & 0.49 & NS & 0.060 & 0.185 \\
\hline Lysine & $2 \cdot 10$ & $1 \cdot 18$ & 0.96 & 0.91 & 0.036 & 0.017 & 0.367 \\
\hline Phenylalanine & 0.95 & 0.90 & 0.68 & 0.63 & NS & 0.045 & 0.159 \\
\hline Serine & 8.68 & 4.42 & 3.35 & $2 \cdot 82$ & 0.026 & 0.011 & 1.818 \\
\hline Threonine & $3 \cdot 31$ & $2 \cdot 82$ & 2.07 & 2.57 & NS & & 1.018 \\
\hline Tyrosine & $1 \cdot 111$ & 0.91 & 0.77 & 0.78 & NS & 0.040 & 0.143 \\
\hline Valine & 0.79 & 0.65 & 0.48 & 0.54 & 0.058 & 0.033 & 0.106 \\
\hline
\end{tabular}

M, maintenance energy.

${ }^{\star}$ For details of diets and procedures, see p. 168.

† Mean values for water contents of plasma and muscle were 0.931 and 0.836 respectively. $\ddagger$ d.f. 13 (two missing values). 

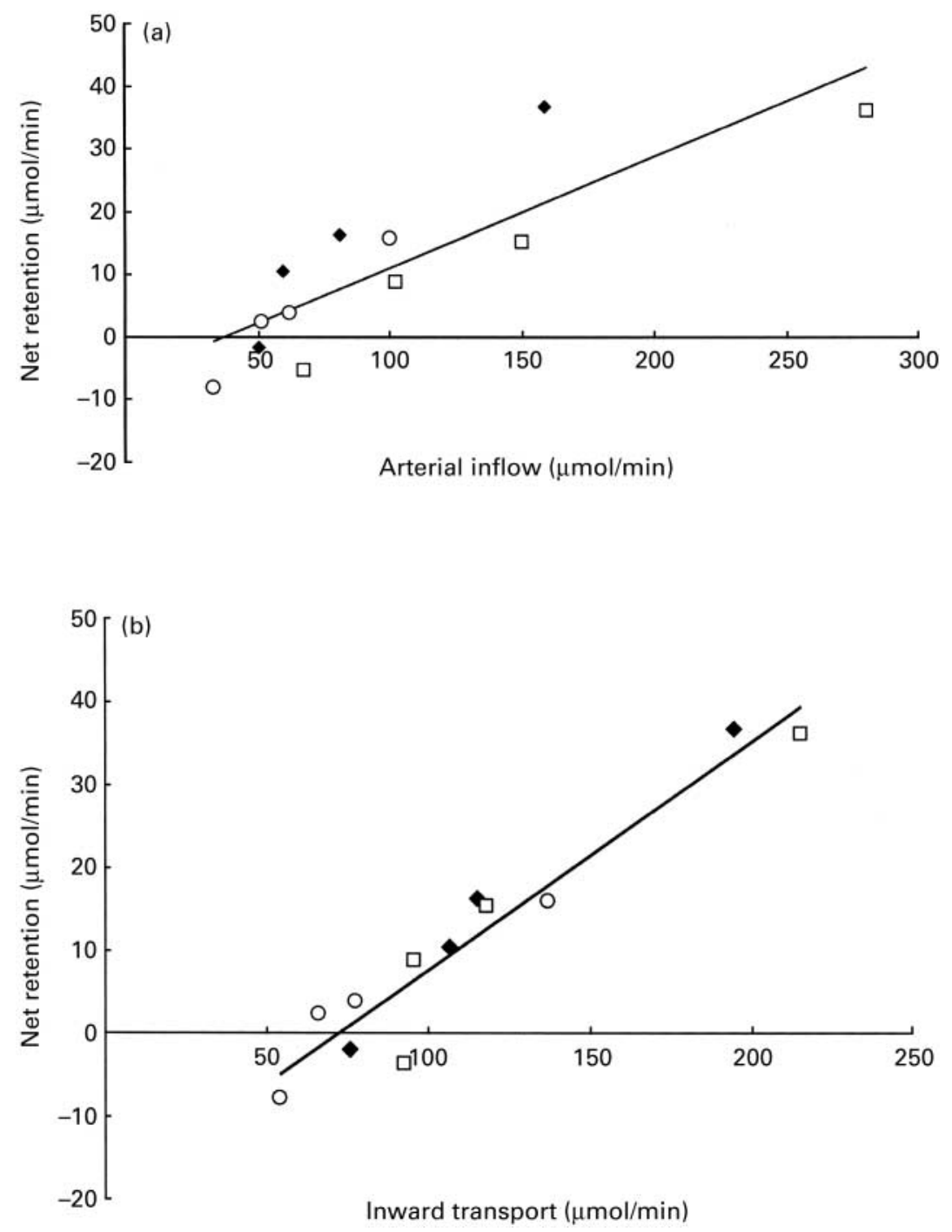

Fig. 2. Amino acid ( $\diamond$, leucine; $\bigcirc$, threonine; $\square$, valine) kinetics in sheep in response to alteration of intake from 0.5 to $2.5 \times$ maintenance energy. Response in net retention to either (a) altered amino acid supply via arterial inflow $\left(y=0.177 x-6.64, R^{2}\right.$ $0.73)$ or (b) transport of amino acid into cells of hindquarter tissues $(y=0.276 x-$ 19.97, $R^{2}$ 0.92). For details of diets and procedures, see p. 168.

passing through nutritive capillaries exchanges fully with adjacent cells and that metabolic extraction depends on the 'nutritive' flow: 'non nutritive' flow value. An alternative hypothesis would stress the importance of differences between individual metabolites and cells. The latter would account for scenarios where some metabolites are completely extracted across a tissue while others are not, e.g. nearly $100 \%$ propionate and $\mathrm{NH}_{3}$ total inflows to the liver are removed (e.g. Eisemann et al. 1996; Nieto et al. 1996), while AA extractions can be $<10 \%$ (e.g. WrayCahen et al. 1997; Lobley et al. 2001). In the current study, the second hypothesis also appears more probable, as the 4-fold differences in the $F_{m a}: F_{\text {in }}$ ratio $(0 \cdot 13-0.50)$ for the various AA clearly indicate differential extraction efficiencies, even though vascular distribution would be similar.

With regard to the first question posed, intake did influence the absolute amounts of individual AA transported into muscle, but this was a function of increased supply $\left(F_{i n}\right)$ to the tissues rather than a change in the 'transport efficiency' (i.e. $F_{m a}: F_{\text {in }}$ ). Furthermore, the differential in $F_{m a}: F_{\text {in }}$ ratio observed between individual AA was maintained across a wide intake range. Thus, an important feature of AA transport appeared to be total supply (i.e. the combination of blood flow and arterial concentrations) to the tissues. The constancy of 'transport efficiency' may be a feature of changing total intake and thus maintaining similar relative proportions of the individual AA. If one AA becomes limited then its extraction can reach nearly $100 \%$, as observed across the mammary gland of lactating goats during histidine deficiency (Bequette et al. 2000).

\section{Transport, protein synthesis and retention}

Feed intake altered the amount of AA transported into the tissues, but did this limit either protein retention or 
synthesis? Less than $50 \%$ arterial AA flow exchanged with the hindlimb tissues, yet this still provided a large excess of AA compared with the needs for net retention. Indeed, at the highest intakes and rates of protein accretion (Hoskin et al. 2001), the proportion of inward transport retained did not exceed $40 \%$. In addition, even when there was net mobilisation of protein by the hindquarter tissues (i.e. net outward transfer), inward transport was still considerable. Thus, absolute rates of inward transport did not appear to limit protein accretion. In practice, net gain may be limited by the inward transport of just one AA, with transfers of the rest being in 'excess' of metabolic needs. Due to technical problems and limitations not all AA were evaluated: notable omissions included methionine and tryptophan and it must be assumed that neither of these was limiting. One alternative possibility is that retention is a function of transport greater than some 'basal' value, but even when differences between the highest and lowest intake were considered, $<30 \%$ of the incremental inward transport was retained for most of the essential AA and branched-chain AA. Again, this can be seen graphically for the three AA (Fig. 2(b)). The exception was histidine, where the increased retention exceeded the extra transfer into the cell (123\%). Furthermore, because increased transport of one AA can stimulate the uptake of others (Oxender \& Christensen, 1963; Jacquez, 1967; Shennan et al. 1994), altered metabolism of just a few AA might provoke the universal responses observed here. This needs to be examined further.

Why does AA transport increase with intake when sufficient material is apparently already available to the cell? One possibility relates to preferential use of specific AA pools for metabolic purposes, i.e. 'compartmentalisation'. For example, the rates of inward transport and protein synthesis were similar for many of the essential AA. In theory, protein synthesis can arise from AA that have just entered the cell or those released from protein degradation (plus any synthesised de novo in the case of the nonessential AA). If protein synthesis occurred mainly from AA that entered the cell, with conversely those liberated from proteolysis directed towards efflux, then rates of inward transport would need to be both high and sensitive to intake. Unfortunately, evidence for such cellular compartmentalisation appears weak. Although in some tissues, such as the liver, polypeptide synthesis can involve AA newlytransported into the cell, this appears to be confined mainly to export proteins (Fern \& Garlick, 1976; Connell et al. 1997), with constitutive proteins synthesised from intracellular pools (Fern \& Garlick, 1976; Smith \& Sun, 1995). In muscle, proteins appear to be synthesised from AA in the intracellular compartment, as shown in a variety of studies involving either reciprocal pool or large dose approaches (e.g. Horber et al. 1989; Lobley et al. 1992; Watt et al. 1992; Ljungqvist et al. 1997). Thus, the large inward transport rates do not appear to be a feature of compartmentalisation but, instead, may confer metabolic flexibility and the ability to respond rapidly to changes in substrate supply or hormonal changes without the delay incurred if synthesis or recruitment of transporters were needed. This would be in line with metabolic control logic (Newsholme \& Board, 1991).

\section{Intake effects on tissue homogenate concentrations of amino acids}

Another putative regulator of protein synthesis and accretion could be intracellular concentrations of AA. These are a function of the inflows (inward transport, protein degradation, synthesis de novo ) and outflows (efflux, protein synthesis and AA catabolism) and clearly would be influenced by changes in rates of transport. Despite the differences in AA kinetics in response to intake, however, this did not result in consistent changes of the free essential AA concentrations in the homogenate, either within or between muscle and skin. This may be due to the links between counter-regulatory transport mechanisms (Christensen, 1990) with influx-driven increases in rate of efflux (Shennan et al. 1994; Ferruzza et al. 1997). Indeed, the current results do indicate that increased AA inward transport is associated with elevated efflux, but such responses may differ between tissues. For example, when a large dose of an AA transported mainly by the L-system is injected into sheep then the concentrations of other AA co-transported by the L-system increase in skin, but either decrease, or remain unaltered, in muscle (Rocha et al. 1993). Nonetheless, any changes in homogenate AA concentrations may have limited effect, because in the process of protein synthesis the $K_{\mathrm{m}}$ for aminoacyl tRNA transferases rarely exceeds $1-2 \mu \mathrm{M}$ (e.g. Nazarenko et al. 1992). Therefore, any increase of homogenate concentrations beyond the $50-250 \mu \mathrm{M}$ already found at low intakes will not exert a mass action effect on protein synthesis.

\section{Inter-species comparisons}

There are only a limited number of studies that have measured, or estimated, AA transport into tissues. Direct estimates for muscle have been reported for rodents, both in vivo (Banos et al. 1973) and for the perfused hindlimb (Hundal et al. 1989), while values for dogs (Biolo et al. 1992), rabbits (Zhang et al. 1998) and human subjects (Biolo et al. 1995) have been obtained by the procedure adopted in the current study. Based on the assumption that sheep hindquarters represent $18 \%$ body weight (Harris et al. 1992), then inter-species comparisons of normalised results reveal that rates of inward AA transport were rat $>\operatorname{dog}=$ sheep $>$ rabbit $=$ human subjects. For example, inward transport rates for phenylalanine were (nmol/min per g tissue): rat 7.7, $\operatorname{dog} 4.2$, sheep (low to high intake) $1.9-4 \cdot 0$, human subjects 1.9 , rabbit (fasting and plus AA) $1 \cdot 1-1 \cdot 9$. The same order is found when rates of fractional protein synthesis in muscle between these species are compared (e.g. Lewis et al. 1984; Garlick et al. 1989; Lobley et al. 1992; Caso et al. 2001). Thus, the various experimental approaches all provide indirect support for a relationship between inward AA transport and tissue protein turnover.

While for most AA, enrichments in both muscle and skin were similar, suggesting that the proportional inflows into the homogenate pool from inward transport and protein degradation were similar between the two tissues, this was not the case for histidine. For this AA, intra-muscular 
enrichments (but not those in skin) were low compared with other AA. The histidine content of ovine muscle protein in the current study was not unusual (Macrae et al. 1993), so homogenate release from protein degradation should be in reasonable proportion relative to other AA. Thus, the results suggest that either inward transport into muscle is low or that other, unlabelled, sources of histidine are available to the tissue. Low rates of histidine transport into muscle are not a feature of other species (e.g. rat; Banos et al. 1973) and thus this explanation would require a specific feature of ovine (or ruminant animal) metabolism. Histidine may also be liberated from carnosine ( $\beta$-alanylhistidine), present in large concentrations in muscle (Maynard et al. 2001), and can provide the AA in times of histidine deficiency (Tamaki et al. 1977). This would act as a source of unlabelled histidine (in the short-term). This may be similar to the situation in ovine erythrocytes, where histidine concentration exceeds that of plasma, but has much lower enrichment (Lobley et al. 1996). Histidine in muscle, therefore, may be either sourced from small peptides or exchanged directly with the erythrocyte.

In summary, most of the AA examined showed similar generalised responses to increased food intake. Thus, both cellular influx and efflux of AA were elevated, as was protein turnover. Despite this, absolute rates of AA transport did not appear to limit protein anabolism and strategies to enhance AA transport in order to increase anabolic responses to food intake are likely to have limited benefit. As supply to the cell of precursor AA appeared to be always in considerable excess to that necessary for gain, then other factors, such as hormonal action, must be the key regulators. The scope of the present study was limited to effects of feed intake, with the sole focus on transport of AA from arterial supply into tissues of the ovine hindquarters. It is almost certain that hormonal and endocrine factors such as insulin and insulin-like growth factor 1 (Lobley, 1998), the plasma concentrations of which alter with feed intake, were involved in the changes in protein metabolism observed in the present study. However, investigation of these factors and their interactions with AA transport requires alternative approaches (Davis et al. 2002) that were beyond the scope of the present study. Nonetheless, as neither total AA supply nor inward transport appear to limit protein gain or metabolism within muscle, then such areas do need to be investigated as a matter of urgency.

\section{Acknowledgements}

The surgical expertise of Mrs N. Dennison is gratefully recognised. The technical support of D. M. Bremner, S. E. Anderson and K. Garden was invaluable for this project. This research was funded in part by SEERAD, from the core budget to the Rowett Research Institute. S. O. H. was the recipient of a post-doctoral fellowship from The Foundation for Research, Science and Technology, New Zealand.

\section{References}

Banos G, Daniel PM, Moorhouse SR \& Pratt OE (1973) The movement of amino acids between blood and skeletal muscle in the rat. Journal of Physiology 235, 459-475.

Bequette BJ, Hanigan MD, Calder AG, Reynolds CK, Lobley GE \& MacRae JC (2000) Amino acid exchange by the mammary gland of lactating goats when histidine limits milk production. Journal of Dairy Science 83, 765-775.

Biolo G, Chinkes D, Zhang X-J \& Wolfe RR (1992) A new model to determine in vivo the relationship between amino acid transmembrane transport and protein kinetics in muscle. Journal of Parenteral and Enteral Nutrition 16, 305-315.

Biolo G, Fleming RYD, Maggi SP \& Wolfe RR (1995) Transmembrane transport and intracellular kinetics of amino acids in human skeletal muscle. American Journal of Physiology 268, E75-E84.

Biolo G, Gastaldelli A, Zhang X-J \& Wolfe RR (1994) Protein synthesis and breakdown in skin and muscle: a leg model of amino acid kinetics. American Journal of Physiology 267, E467-E474.

Boisclair YR, Bell AW, Dunshea FR, Harkins M \& Bauman DE (1993) Evaluation of the arteriovenous difference technique to simultaneously estimate protein synthesis and degradation in the hindlimb of fed and chronically underfed steers. Journal of Nutrition 123, 1076-1088.

Calder AG, Garden KE, Anderson SE \& Lobley GE (1999) Quantitation of blood and plasma amino acids using isotope dilution mass spectrometry impact gas chromatography/mass spectrometry with $\mathrm{U}-{ }^{13} \mathrm{C}$ amino acids as internal standards. Rapid Communications in Mass Spectrometry 13, 2080-2083.

Cant JP, Qiao F \& Toerien CA (1999) Regulation of mammary metabolism. In Protein Metabolism and Nutrition. European Association for Animal Production Publication no. 96, pp. 203-220 [GE Lobley, A White and JC MacRae, editors]. Wageningen: Wageningen Pers.

Caso G, Ford GC, Nair KS, Vosswinkel JA, Garlick PJ \& McNurlan MA (2001) Increased concentration of tracee affects estimates of muscle protein synthesis. American Journal of Physiology 280, E937-E946.

Christensen HN (1990) Role of amino acid transport and countertransport in nutrition and metabolism. Physiological Reviews 70, $43-78$.

Connell A, Calder AG, Anderson SE \& Lobley GE (1997) Hepatic protein synthesis in the sheep: effect of intake as monitored by use of stable-isotope-labelled glycine, leucine and phenylalanine. British Journal of Nutrition 77, 255-271.

Davis TA, Fiorotto ML, Burrin DG, Reeds PJ, Nguyen HV, Beckett PR, Vann RC \& O'Connor PM (2002) Stimulation of protein synthesis by both insulin and amino acids is unique to skeletal muscle in neonatal pigs. American Journal of Physiology 282, E880-E890.

Davis TA, Fiorotto ML, Nguyen HV \& Burrin DG (1999) Aminoacyl-tRNA and tissue free amino acid pools as equilibrated after a flooding dose of phenylalanine. American Journal of Physiology 277, E103-E109.

Dawson JM, Buttery PJ, Lammiman MJ, Soar JB, Essex CP, Gill M \& Beever DE (1991) Nutritional and endocrinological manipulation of lean deposition in forage-fed steers. British Journal of Nutrition 66, 171-185.

Eisemann JH, Huntington GB \& Catherman DR (1996) Patterns of nutrient interchange and oxygen use among portal-drained viscera, liver, and hindquarters of beef steers from 235 to $525 \mathrm{~kg}$ body weight. Journal of Animal Science $\mathbf{7 4}$. $1812-1831$.

Fern EB \& Garlick PJ (1976) Compartmentation of albumin and 
ferritin synthesis in rat liver in vivo. Biochemical Journal 156, 189-192.

Ferruzza S, Ranaldi G, Di Girolamo M \& Sambuy Y (1997) The efflux of lysine from the basolateral membrane of human cultured intestinal cells (Caco-2) occurs by different mechanisms depending on the extracellular availability of amino acids. Journal of Nutrition 127, 1183-1190.

Garlick PJ, Wernerman J, McNurlan MA, Essen P, Lobley GE, Milne E, Calder GA \& Vinnars E (1989) Measurement of the rate of protein synthesis in muscle of postabsorptive young men by injection of a 'flooding dose' of $\left[1-{ }^{13} \mathrm{C}\right]$ leucine. Clinical Science 77, 329-336.

Harris PM, Lee J, Sinclair BR, Treloar BP \& Guernsey MP (1994) Effect of food intake on energy and protein metabolism in the skin of Romney sheep. British Journal of Nutrition 71, 647-660.

Harris PM, Lobley GE, Skene PA, Buchan V, Calder AG, Anderson SE \& Connell A (1992) Effect of food intake on hind limb and whole body protein metabolism in growing sheep: chronic studies based on arteriovenous techniques. British Journal of Nutrition 68, 389-407.

Horber FF, Horber-Feyden CM, Schwenk WF \& Haymond MW (1989) Plasma reciprocal pool specific activity predicts that of intracellular free leucine for protein synthesis. American Journal of Physiology 257, E385-E399.

Hoskin SO, Savary IC, Zuur G \& Lobley GE (2001) Effect of feed intake on ovine hindlimb protein metabolism based on thirteen amino acids and arterio-venous techniques. British Journal of Nutrition 86, 577-585.

Hundal HS, Rennie MJ \& Watt PW (1989) Characteristics of acidic, basic and neutral amino acid transport in the perfused rat hindlimb. Journal of Physiology 408, 93-114.

Jacquez J (1967) Competitive stimulation: further evidence for two carriers in the transport of neutral amino acids. Biochemica et Biophysica Acta 135, 751-755.

Lescoat P, Sauvant D \& Danfaer A (1996) Quantitative aspects of blood and amino acid flows in cattle. Reproduction Nutrition Development 36, 137-174.

Lewis SE, Kelly FJ \& Goldspink DF (1984) Pre- and post-natal growth and protein turnover in smooth muscle, heart and slow- and fast-twitch skeletal muscles of the rat. Biochemical Journal 217, 517-526.

Liu SM, Mata G, O’Donoghue H \& Masters DG (1998) The influence of live weight, live-weight change and diet on protein synthesis in the skin and skeletal muscle in young Merino sheep. British Journal of Nutrition 79, 267-274.

Ljungqvist OH, Persson M, Ford GC \& Nair KS (1997) Functional heterogeneity of leucine pools in human skeletal muscle. American Journal of Physiology 273, E564-E570.

Lobley GE (1993) Species comparisons of tissue protein metabolism: effects of age and hormonal action. Journal of Nutrition 123, 337-343.

Lobley GE (1998) Nutritional and hormonal control of muscle and peripheral tissue metabolism in farm species. Livestock Production Science 56, 91-114.

Lobley GE, Bremner DM \& Brown DS (2001) Responses in hepatic removal of amino acids by the liver to short-term infusions of varied amounts of an amino acid mixture into the intramesenteric vein. British Journal of Nutrition 85, 689-698.

Lobley GE, Connell A, Revell DK, Bequette BJ, Brown DS \& Calder AG (1996) Splanchnic-bed transfers of amino acids in sheep blood and plasma, as monitored through use of a multiple $\mathrm{U}-{ }^{13} \mathrm{C}$-labelled amino acid mixture. British Journal of Nutrition 75, 217-235.

Lobley GE, Harris PM, Skene PA, Brown D, Milne E, Calder AG, Anderson SE, Garlick PJ, Nevison I \& Connell A (1992) Responses in tissue protein synthesis to sub- and supra-maintenance intake in young growing sheep: comparison of large dose and continuous infusion techniques. British Journal of Nutrition 68, 373-388.

MacRae JC, Walker A, Brown D \& Lobley GE (1993) Accretion of total protein and individual amino acids by organs and tissues of growing lambs and the ability of nitrogen balance techniques to quantitate protein retention. Animal Production 57, 237-245.

Maynard LM, Boissonneault GA, Chow CK \& Bruckner GG (2001) High levels of dietary carnosine are associated with increased concentrations of carnosine and histidine in rat soleus muscle. Journal of Nutrition 131, 287-290.

Nazarenko IA, Peterson ET, Zakharova OD, Lavrik OI \& Uhlenbeck OC (1992) Recognition nucleotides for human phenylalanyl-tRNA synthetase. Nucleic Acids Research 20, 475-478.

Newsholme EA \& Board M (1991) Application of metabolic-control logic to fuel utilization and its significance in tumor cells. Advances in Enzyme Regulation 31, 225-246.

Nieto R, Calder AG, Anderson SE \& Lobley GE (1996) Method for the determination of ${ }^{15} \mathrm{NH}_{3}$ enrichment in biological samples by gas chromatography/electron impact ionization mass spectrometry. Journal of Mass Spectrometry 31, 289-294.

Oddy VH, Lindsay DB, Barker PJ \& Northrop AJ (1987) Effect of insulin on hindlimb and whole-body leucine and protein metabolism in fed and fasted lambs. British Journal of Nutrition 58, 437-452.

Oxender DL \& Christensen HN (1963) Distinct mediating systems for the transport of neutral amino acids by the Erhlich cell. Journal of Biological Chemistry 238, 3686-3699.

Ponter AA, Cortamira NO, Seve B, Salter DN \& Morgan LM (1994) The effects of energy source and tryptophan on the rate of protein synthesis and on hormones of the entero-insular axis in the piglet. British Journal of Nutrition 71, 661-674.

Prosser CG, Davis SR, Farr VC \& Lacasse P (1996) Regulation of blood flow in the mammary microvasculature. Journal of Dairy Science 79, 1184-1197.

Rocha HG, Nash J, Connell A \& Lobley GE (1993) Protein synthesis in ovine muscle and skin: sequential measurements with three different amino acids based on the large dose procedure. Comparative Biochemistry and Physiology 105B, 301-307.

Savary IC, Hoskin SO, Dennison N \& Lobley GE (2001) Lysine metabolism across the hindquarters of sheep; effect of intake on transfers from plasma and the red blood cells. British Journal of Nutrition 85, 565-573.

Savary-Auzeloux IC, Hoskin SO \& Lobley GE (2002) Effect of intake on whole body plasma amino acid kinetics in sheep. Reproduction, Nutrition and Development (In the Press).

Seve B, Reeds PJ, Fuller MF, Cadenhead A \& Hay SM (1986) Protein synthesis and retention in some tissues of the young pig as influenced by dietary protein intake after early weaning - possible connection to the energy metabolism. Reproduction, Nutrition and Development 26, 849-861.

Shennan DB, McNeillie SA, Jamieson EA \& Calvert DT (1994) Lysine transport in lactating rat mammary tissue: evidence for an interaction between cationic and neutral amino acids. Acta Physiologica Scandinavica 151, 461-466.

Smith CB \& Sun Y (1995) Influence of valine flooding on channeling of valine into tissue pools and on protein synthesis. American Journal of Physiology 268, E735-E744.

Tamaki N, Tsunemori F, Wakabayashi M \& Hama T (1977) Effect of histidine-free and -excess diets on anserine and carnosine contents in rat gastrocnemius muscle. Journal of Nutritional Science and Vitaminology 23, 331-340.

Watt PW, Corbett ME \& Rennie MJ (1992) Stimulation of protein synthesis in pig skeletal muscle by infusion of amino acids 
during constant insulin availability. American Journal of Physiology 263, E453-E460.

Wray-Cahen D, Metcalf JA, Backwell FRC, Bequette BJ, Brown DS, Sutton JD \& Lobley GE (1997) Hepatic response to increased exogenous supply of plasma amino acids by infusion into the mesenteric vein of Holstein-Friesian cows in late gestation. British Journal of Nutrition 78, 913-930.

Zhang X-J, Chinkes DL, Doyle D Jr \& Wolfe RR (1998) Metabolism of skin and muscle protein is regulated differently in response to nutrition. American Journal of Physiology 274, E484-E492. 